\title{
Changes in travel behavior during the transition from secondary to higher education: A case study from Ghent, Belgium
}

\author{
Leen De Paepe \\ Ghent University \\ Leen.DePaepe@UGent.be \\ Veronique Van Acker \\ Luxembourg Institute of Socio-Economic \\ Research \\ Veronique.VanAcker@liser.lu
}

\author{
Jonas De Vos \\ Ghent University \\ Jonas.DeVos@UGent.be \\ Frank Witlox \\ Ghent University \\ Frank.Witlox@UGent.be
}

\begin{abstract}
Over the past few decades, the number of students attending universities and university colleges in Belgium has increased considerably. In many Western countries, this trend is accompanied by a decline in car use among young adults. Therefore, it is important to have better insights into how travel behavior changes during the transition from secondary to higher education. This research fits into the larger framework of mobility biographies, where travel behavior is analyzed over a life course, taking into account certain life events. Hierarchical logistic regressions are used to analyze car use data for mandatory activities (going to school and grocery shopping) and leisure activities (fun shopping) of 404 first-year university and university college students in Ghent (Belgium). The results indicate that holding a driver's license or owning a car facilitates car use irrespective of students' residential location and lifestyle, and this is true for all activities. The built environment only seems to become an important factor explaining car use when students are attending university or university college. The influence of lifestyles appears to become somewhat more important for leisure activities, such as fun shopping. The emerging lifestyle of students appears to become more individual and more independent from the lifestyle of others, especially the parents. This is supported by the declining influence of social networks, notably the family.
\end{abstract}

Keywords: Modal choice, mobility biographies, lifestyles, students, Belgium

\section{Article history:}

Received: November 13, 2016

Received in revised form:

February 12, 2018

Accepted: April 13, 2018

Available online: July 9, 2018

Copyright 2018 Leen De Paepe, Jonas De Vos, Veronique Van Acker \& Frank Witlox http://dx.doi.org/10.5198/jtlu.2018.1113

ISSN: 1938-7849 | Licensed under the Creative Commons Attribution - Noncommercial License 4.0

The Journal of Transport and Land Use is the official journal of the World Society for Transport and Land Use (WSTLUR) and is published and sponsored by the University of Minnesota Center for Transportation Studies. This paper is also published with additional sponsorship from WSTLUR. 


\section{$1 \quad$ Introduction}

Over the past few decades, the number of students that enter universities and university colleges in Belgium has increased substantially. Several reasons explain this trend. Universities and university colleges have become more accessible because of the so-called democratization of the higher education system. Young adults are also more convinced that holding a degree increases their job opportunities. In addition, since fewer jobs are available to them, young adults tend to postpone their job search and study longer (Steunpunt Werk en Sociale Economie, 2012). In many Western countries, this trend is accompanied by a decline in car use among young adults (Delbosc \& Currie, 2013; Kuhnimhof et al. 2012a). Therefore, it is important to gain better insights into the current modal choice of this expanding group of students and to understand how this modal choice changes over time.

This paper provides insights into the modal choices of students who make the transition from secondary to higher education. In Belgium, these students are 18 to 19 years old. The following four research questions are put forward: (i) What are the attitudes toward mobility among students in higher education, and are there important differences between past and current attitudes? (ii) How do modal choices, especially car use, change during the transition from secondary to higher education? (iii) Do lifestyles influence modal choices, even after controlling for socio-economic and demographic characteristics, the built environment, and the social network? (iv) Are the results different for mandatory and leisure activities?

\section{$2 \quad$ Literature}

\subsection{Travel behavior of young adults}

Around the turn of the millennium, many Western countries reached 'peak car' status (Goodwin, 2012; Goodwin \& Van Dender, 2013). After decades of growth, Millennials or Generation Y (people born between 1980 and 2000) are now less likely to obtain a driver's license and even if they do get a license, they are driving less (Chatterjee et al., 2017; Delbosc, 2017; Delbosc \& Currie, 2013, 2014a; Kuhnimhof et al., 2012a). The decline in the driver's license rate is apparent among students and young adults living in urban areas (Cedersund \& Henriksson, 2006; Hjorthol, 2016; Krantz, 1999; Le Vine \& Jones, 2012; McDonald \& Trowbridge, 2009; Nordbakke, 2002). Berrington and Mikolai (2014) add that young adults living in the parental home are also less likely to drive (despite having a driver's license) and suggest that the driver's license rate among these young adults will further decline. Many young adults use car transportation less often in favour of public transport, cycling, and walking (Goodwin, 2012; Hjorthol \& Bjørnskau, 2005; Kuhnimhof et al., 2012a; Kuhnimhof, Buehler, Wirtz, \& Kalinowska, 2012b). It is, however, not clear whether this is because young adults who live in urban areas feel less the need of having a driver's license or because they do not have a license and therefore need to live in more accessible areas (Berrington \& Mikolai, 2014).

The decline in car use can possibly be explained by changing attitudes toward the environment and mobility. A Dutch study by Jorritsma \& Berveling (2014) suggests that private ownership (such as a car) is being replaced by using services and that the smartphone is replacing the car as a status symbol, possibly due to more environmental awareness (Berrington \& Mikolai, 2014; Delbosc \& Currie, 2013; Kuhnimhof et al., 2012a). Some studies (Sivak \& Schoettle, 2012) argue that e-communication reduces young adults' need for mobility by replacing face-to-face communication. This favors the use of public transport since it is forbidden to use a mobile phone while driving (Berrington \& Mikolai, 2014). Ad- 
ditionally, smartphone applications might facilitate the use of public transport with real-time and other useful information (Delbosc \& Currie, 2013; Sakaria \& Stehfest, 2013). It is also possible that young adults adopt an urban lifestyle independent of the car because they perceive it as more practical. When they live and work in the same city, distances become shorter and it becomes easier to access different activities (Hjorthol, 2016; Hjorthol \& Bjørnskau, 2005). Another possible reason is that young adults perceive a car as rather expensive because of increasing costs of insurance, obtaining a driver's license, the cost of fuel, maintenance, and taxes (Latinopoulos, Le Vine, Jones, Polak, 2013; Le Vine, Polak, \& Kuhnimhof, 2013; Noble, 2005; Office for National Statistics, 2013).

However, other research shows that young adults are not necessarily more environmentally aware or less car-oriented than older generations (Delbosc \& Currie, 2014b; Le Vine, Jones, Lee-Gosselin, \& Polak, 2014; Van Acker, 2017). Many young adults feel the need to buy a car in the future (Jorritsma \& Berveling, 2014; Swinnen \& Valkeneers, 2002). Some say that a car can still be perceived as a symbol of social status (Berrington \& Mikolai, 2014; Deloitte, 2009). Others mention that the car is more related to elements such as responsibility, freedom, independence, and comfort (Delbosc \& Currie, 2014b; Jorritsma \& Berveling, 2014). A car and a house in the suburbs still remain a common future ideal for many young adults (Jamieson, Cunningham-Burley, \& Rawlins, 2012). It also seems that ecommunication is not replacing face-to-face communication, but is instead seen as a supplement to it (Delbosc \& Currie, 2013).

It is important that policy makers try to change travel behavior of young adults in favor of more sustainable travel modes. It is possible that changes to the built environment indirectly affect attitudes toward the environment and travel modes (De Vos, Derudder, Van Acker, \& Witlox, 2012; Kitamura, Mokhtarian, \& Laidet, 1997). However, it is also important to influence attitudes directly, because they have an important influence on the environment and the travel mode choice (Bagley \& Mokhtarian, 2002). If travel behavior is explained by attitudes, then travel behavior will be rather stable. For example, if car use by young adults decreases, this trend will possibly continue. But if travel behavior is explained by the built environment and socio-economic characteristics, then travel behavior will be temporary. If young adults start to work or move, travel behavior will possibly change again in favor of the car (Delbosc \& Currie, 2013; Jorritsma \& Berveling, 2014).

\subsection{Mobility biographies}

This research fits into the larger framework of using mobility biographies to study travel behaviour (Beige \& Axhausen, 2006; Lanzendorf, 2003; Müggenburg, Busch-Geertsema, \& Lanzendorf, 2015; Scheiner, 2007). The basic idea is that, in general, travel behavior is rather stable and constant, but it can change due to certain important life events. We know that different dimensions affect travel behavior: personal, social, temporal, and spatial. An individual can be influenced by a personal experience toward mobility (Scheiner \& Holz-Rau, 2013). An individual can also be influenced by mobility socialization. Individuals are mainly affected by their family, but they can also be influenced by friends, fellow students, colleagues, and other social groups (Döring, Albrecht, Scheiner, \& Holz-Rau, 2015; Haustein, Klöckner, \& Blöbaum, 2009). An individual can be influenced by the past (lagged effect), the present (situational effect), or by expectations toward the future (lead effect) (Albrecht, Döring, Holz-Rau, \& Scheiner, 2014; Van Acker, 2015). Besides these dimensions, historical, political, and technological contexts will also impact travel behavior (Döring et al., 2015). Objective variables, such as the built environment and socio-economic characteristics, and subjective variables, such as attitudes, of the transport system are specific to a socio-cultural setting. This can be described as mobility cultures, which consist of mobility-related discourses and political strategies as well as institutionalized travel patterns and the built environment (Deffner et al., 2006; Götz \& Deffner, 2009; Klinger, Kenworthy, \& Lazendorf, 
2013). Individuals must adapt to these different dimensions and contexts and every alternative must be carefully taken into consideration.

Life events influence the education or employment, residential, household, and mobility biography. These biographies are interrelated and changes in one type of biography can influence other biographies (Döring et al., 2015; Scheiner \& Holz-Rau, 2013). The effects of several work-related life events on travel behavior have been examined in previous studies. Concerning the education or work biography and mobility biography, the entry into the labor market (Harms, 2007), income changes (Dargay, 2001), and retirement (Ottmann, 2007) have all been explored. The transition from secondary to higher education is an important life event which can change travel behavior. However, to our knowledge, changes in travel behavior during the transition from secondary to higher education have received little to no attention in travel behavior research.

\subsection{Lifestyles and attitudes}

Travel behavior is a multidimensional concept comprising elements such as travel mode choice and trip characteristics (e.g., trip frequency, travel distance, and travel time), and is affected by elements such as people's activity patterns, the built environment and the social environment (Mokhtarian \& Cao, 2008; van Wee, 2002). In the past, academics mainly explained travel behavior by objective variables such as the built environment, and socio-economic characteristics. Since the 1990s, subjective variables like attitudes and lifestyles have been considered (Kitamura et al., 1997; Van Acker, 2016; Van Acker, Goodwin, \& Witlox, 2016). According to Munters (1992), a distinction can be made between lifestyles and lifestyle expressions. A lifestyle is not observable and includes internal opinions, motivations, and orientations. A lifestyle seems to be rather stable and changes will only occur in the long term by changes in attitudes, values, and preferences (Kitamura, 1988). A lifestyle can manifest itself in a lifestyle expression that is observable (Munters, 1992). Therefore, travel behavior can be regarded as a lifestyle expression (Van Acker et al., 2016). In the remainder of this paper, the 'lifestyle' concept is used when referring to multiple personal or individual attitudes.

Lifestyles can partially explain travel behavior and sometimes they even provide a better explanation than the built environment and socio-economic characteristics (Bagley \& Mokhtarian, 2002; De Vos et al., 2012; Kitamura et al., 1997; Schwanen \& Mokhtarian, 2005a, 2005b). Research shows that lifestyles have a significant influence on leisure trips, but they only explain travel behavior to work or grocery stores to a limited degree (Scheiner, 2010; Van Acker, Mokhtarian, \& Witlox, 2011). On the other hand, travel behavior also affects lifestyles. Travel behavior can strengthen related attitudes. For example, when people use their car more often, attitudes toward car use will probably become more positive while the attitudes toward other modes might become more negative (Bagley \& Mokhtarian, 2002).

\section{Data and methodology}

\subsection{Questionnaire}

Data for this study was collected in the city of Ghent (Belgium). An online survey was organized among first-year students of the higher education institutions present in Ghent. Around the time of the research (2013-2014), there were approximately 12,192 first-year students enrolled in higher education in Ghent (Stad Gent, 2016). Students were asked information about their past and current travel patterns with respect to activities such as education, grocery shopping, and fun shopping, and which travel mode 
they used (car as driver and passenger, train, bus or tram, moped or motorcycle, bicycle, or foot). The survey also contained sections on attitudes toward mobility in general and past and current attitudes toward different travel modes. Furthermore, the influence of previous and current social networks was asked. The survey concluded with several socio-economic and demographic issues. It should be noted that travel information from the last year of the students' secondary education was gathered by asking retrospective questions. As a result, it is possible that a certain level of recall bias occurs.

At the university, the study was announced by email in the monthly newsletter, at several faculties, and on the forums of the digital learning platform of the university. At multiple university colleges, the survey was only distributed via email. Some university colleges refused permission to distribute the invitation to participate in this study. As a solution the study was announced on the Facebook groups of these higher education institutions. Data was collected between December 2013 and January 2014. This resulted in 404 fully completed questionnaires that were used for further analysis. This equals a response rate of 3.3\%, assuming that all first-year higher-education students were informed (which is not the case). This rather low response rate would make it impossible to perform a descriptive analysis of the total population of first-year students of the higher education in Ghent. It has to be noted that low response rates, lower than 10.0\%, are often found in travel behavior studies (Ben-Elia, Alexander, Hubers, \& Ettema, 2014; Cao, 2012; De Vos, Mokhtarian, Schwanen, Van Acker, \& Witlox, 2016a). However, since the main goal of this study is an analytical exploration of the relationship between the independent variables and travel behavior, it is more important to have a large and sufficiently diverse sample than to have a fully representative sample (Groves, 1989). Since our sample size is relatively large and comparable with the sample sizes in many other travel behavior studies, it is possible to estimate the coefficients to characterize specific relationships with reasonable confidence and precision.

A distinction was made between students who commute to Ghent and students who live in student dorms in Ghent. The sample includes $62.8 \%$ commuting students and $37.2 \%$ students who lived in student dorms. More than half of the students (59.2\%) lived in an urbanized environment. Most of the students $(81.9 \%)$ were born in 1995 and were 18 years old at the time of the survey. Almost threequarters of the students were women $(72.8 \%)$. Almost one-third of the students $(30.0 \%)$ held a driver's license and more than half of the households $(60.5 \%)$ owned two cars.

\subsection{Conceptual framework}

Explaining travel behavior is rather complex. This complexity is shown in Figure 1, presenting a conceptual model of travel behavior during the transition from secondary to higher education (based on Van Acker, van Wee, \& Witlox, 2010). This conceptual model will be used to organize this research.

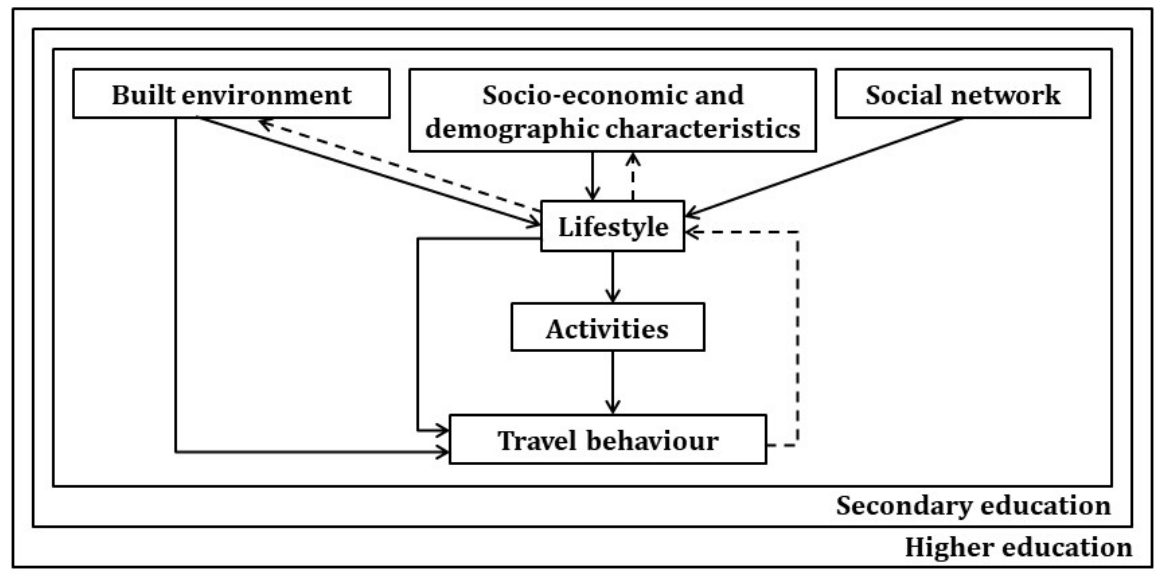

Figure 1: Conceptual model of travel behavior during the transition from secondary to higher education 
Lifestyles can affect the choice to live in a particular residential area, but the residential area of young adults is mainly determined by the parents' residential location choice. In this case, the influence of the built environment on lifestyles will be more important. The built environment can also have a direct effect on travel behavior. The socio-economic and demographic (SED) characteristics, such as the family situation, level of education, car ownership or availability, age, and gender, can have an influence on lifestyle. But lifestyles can also affect socio-economic characteristics. Young adults who are more climate aware might be less likely to obtain a driver's license or buy a personal car. Socio-economic and demographic characteristics can also have a direct effect on travel behavior. If a young adult belongs to a single parent household it is possible that there is less money available to use a car. Furthermore, family, friends, other students, and acquaintances can have an impact on the lifestyle of a young adult or even directly on travel behaviorr. This young adult can also influence his or her social network, which is included in the person's lifestyle. A lifestyle is often linked with performing specific activities. These activities are spatially spread, influencing elements such as travel distance and the travel mode choice. People can choose different travel modes partly based on their lifestyle. Travel behavior also tends to strengthen mobility-related attitudes (Kroesen, Handy, \& Chorus, 2017). Travel behavior of first-year university or university college students can be influenced by their travel behavior in secondary school. As a result, travel behavior during secondary education is in the conceptual model in Figure 1 embedded within travel behavior during higher education.

\subsection{Descriptive analysis}

A descriptive analysis shows the past and current modal split for pupils and students to school, grocery stores and fun shops. For going to school, pupils mainly used the bicycle (49.5\%) during secondary education, which was followed by $26.0 \%$ who used the bus or tram. A subdivision between pupils inside and outside Ghent shows that inside Ghent $61.5 \%$ travelled by bicycle and $19.2 \%$ by bus or tram, and that outside Ghent $47.7 \%$ cycled and $27.0 \%$ used the bus or tram to go to school (inside $\mathrm{N}=52$ and outside $\mathrm{N}$ = 352). Compared to outside Ghent, pupils inside Ghent cycled more and made less use of bus or tram. Students who are currently living in student dorms in Ghent mainly cycle to university or university college $(64.2 \%)$, followed by walking $(24.5 \%)$. Students commuting to Ghent mainly travel by public transport (train $53.8 \%$ and bus or tram 22.5\%). A large proportion of students living in Ghent now goes to the university or university college by foot and many commuting students go by train.

For grocery shopping, the car was most commonly used by pupils as a passenger (55.0\%), followed by the bicycle (22.0\%). Inside Ghent $46.2 \%$ travelled as a car passenger and $34.6 \%$ by bicycle, and outside Ghent $56.3 \%$ travelled as a car passenger and $20.2 \%$ cycled. Inside Ghent, pupils cycled again more and made less use of the car as a passenger. Students who live in student dorms mainly go grocery shopping on foot $(46.6 \%)$ or by bicycle $(45.0 \%)$. If students who commute go grocery shopping it is mainly by car as a passenger (42.3\%), followed by the bicycle (24.5\%). The modal choice of commuting students does not change much compared to when they were in secondary school, however, a reasonable share now goes grocery shopping by car as a driver (14.6\%).

For fun shopping, pupils travelled mainly by car as a passenger (47.0\%), or by bus or tram (20.0\%). Inside Ghent $23.1 \%$ travelled as a car passenger and $34.6 \%$ by bus or tram, and outside Ghent $50.6 \%$ travelled as a car passenger and $17.9 \%$ by bus or tram. Inside Ghent, pupils made less use of the car as a passenger and more of the bus or tram. Students who live in student dorms mainly go fun shopping by bicycle $(47.7 \%)$ or on foot $(27.8 \%)$. Students who commute make use of the car as a passenger $(34.0 \%)$ with family and friends to go fun shopping. They also use the bus or tram $(29.2 \%)$ to go fun shopping. 
Commuting students probably travel now less by car as a passenger and more by bus or tram to shops. The modal choice of students living in Ghent appears to change more than that of commuting students.

\subsection{Statistical method}

Travel behavior of participating students was analyzed using logistic regressions. This statistical method examines the probability that a person chooses a specific travel mode for a particular activity. For this study, we look at the probability that a student used or uses the car as a driver or passenger to school, grocery stores, and fun shops. This probability is influenced by elements ranging from socio-economic and demographic characteristics, the built environment, the social network, lifestyles to trip characteristics. The variables were added in SPSS 25 in a hierarchical way in different blocks with the use of the conditional forward selection method. The first block includes the socio-economic ${ }^{1}$ and demographic characteristics, followed by the built environment, the social network ${ }^{1}$, lifestyles, and trip characteristics. This method adds the variables that contribute the most to the model until the model cannot be further improved. The socio-economic and demographic characteristics block includes gender (woman or man), presence of siblings $(\mathrm{Y} / \mathrm{N})$, dual-earner household $(\mathrm{Y} / \mathrm{N})$, the obtained level of secondary education (general secondary education or technical and vocational secondary education), holding a (permanent) driver's license $(\mathrm{Y} / \mathrm{N})$, possession of a car $(\mathrm{Y} / \mathrm{N})$, possession of a bicycle $(\mathrm{Y} / \mathrm{N})$, and car availability in the household $(\mathrm{Y} / \mathrm{N})$. The built environment comprises the urbanized or rural environment based on a classification using the postal code ${ }^{2}$ of the respondents' residential location. The division between urban and rural residents is based on the "Spatial Structure Plan for Flanders" (Ministerie van de Vlaamse Gemeenschap, 1997). This spatial structure plan divides the Flemish municipalities into categories ranging from metropolitan areas to countryside. We consider respondents residing in metropolitan areas to small urban areas as urban residents and respondents residing outside such urban areas as rural residents. Note that this subdivision is rather crude and may have its shortcomings. ${ }^{3}$ Gradual differences in residential neighborhoods are not included in the analyses. Besides, the subdivision is based on administrative units which do not necessarily correspond with the actual built environment. However, as this classification of urban and rural municipalities is of big importance in the "Spatial Structure Plan for Flanders" it has the advantage of putting forward potential spatial planning interventions possibly discouraging car use of students. Furthermore, it has to be noted that Flemish municipalities are relatively small (i.e., average surface area is $43.9 \mathrm{~km}^{2}$ ) — making the subdivision relatively detailed —and that this subdivision has also been used in other empirical studies (De Vos et al., 2012; De Vos, van Acker, \& Witlox, 2016b). The social networks block includes the travel companions (alone, with friends, family, pupils/students, acquaintances, and strangers) toward a specific activity and a trend (overall decrease, no change, or increase) in the number of family, friends, and acquaintances. The lifestyle incorporates attitudes toward mobility in general, past and current attitudes toward specific travel modes (see Section 3.5), and the perceived features of the car (good for my image, independency, environmentally friendly, healthy, relaxing, comfortable, time saving, flexible, cheap, offering privacy, social, safe, reliable, and possibility to perform other activities). To conclude, the trip characteristic travel distance $(<500$ meters, $500 \mathrm{~m}-$ $1 \mathrm{~km}, 1-2 \mathrm{~km}, 2-5 \mathrm{~km}, 5-10 \mathrm{~km}, 10-20 \mathrm{~km},>20 \mathrm{~km}$ ) was added to the model. To get an explorative insight into the relationship between the independent variables and travel behavior, the current

${ }^{1}$ Only partly used for explaining the past travel behaviour.

${ }^{2}$ We do not have the exact residential location of the respondents. Because of this, it is not possible to add specific elements that define the built environment, such as the distance to the closest city center, accessibility, density, diversity, and design.

${ }^{3} \mathrm{~A}$ more extensive subdivision of respondents based on their residential location was possible. However, we chose not to do so because the distinction between the various urban and suburban neighbourhoods is often difficult to make as suburban neighbourhoods in Flanders, Belgium, are rather diverse and predominantly urbanised (Meeus and De Decker, 2013); while the differences in neighbourhoods between rural municipalities and the group of urban municipalities is most clear. 
travel behavior of higher education students will be compared with their past travel behavior during secondary education, using various logistic regressions. The data are cross-sectional and can therefore only give an indication about how students' travel behavior has changed.

\subsection{Lifestyles}

The lifestyle concept needs to be defined before it is added to the statistical model. Using common factor analysis, the concept was defined by exploring the constructs behind the current attitudes toward mobility in general, the past attitudes toward travel modes, and the current attitudes toward travel modes. Respondents were asked to indicate on a 5 -point Likert scale $(1=$ totally disagree, to $5=$ totally agree $)$ how much they agree with general statements about mobility, such as "I like to travel". Respondents were also asked to score (with $0=$ highly dissatisfied, to $10=$ highly satisfied) different travel modes now and in the past. To facilitate the interpretation, a promax rotation was used. A factor analysis, however, is only useful if the initial variables are correlated. This was tested with the Kaiser-Meyer-Olkin Measure of Sampling Adequacy that must be larger than 0.50 and the Bartlett's Test of Sphericity which tests the null hypothesis and suggests that the correlation matrix is equal to the identity matrix. Factor loadings greater than 0.20 in magnitude explain a considerable amount of variance from the original variable. For the different cases, the Kaiser-Meyer-Olkin Measure of Sampling Adequacy is larger than 0.50 and the null hypothesis can be rejected.

Table 1: Pattern matrix of general attitudes toward mobility $(\mathrm{N}=404)$

\begin{tabular}{lccc}
\hline & Travel liking & Pro-car & Travel disliking \\
\hline I like to travel & 0.674 & & \\
Travelling is a waste of time & -0.661 & 0.576 & 0.484 \\
The majority of my friends have a car & & 0.406 & 0.701 \\
People look down on public transport, cycling and walking & & -0.349 \\
People expect that I buy a car in the next 10 years & & 0.260 \\
I feel frustrated in traffic & & & \\
I feel safe in traffic & & \\
I think public transport is complicated
\end{tabular}

$54.4 \%$ explained variance

Kaiser-Meyer-Olkin Measure of Sampling Adequacy: 0.568

Bartlett's Test of Sphericity: $\chi^{2}=245.475 ; \mathrm{df}=28 ; \mathrm{p}=0.000$

The attitudes toward mobility in general are shown in Table 1 . Three possible factors can be identified: travel liking, pro-car, and travel disliking. Travel liking refers to students who like to travel and do not see travel as a waste of time. Pro-car refers to students who are influenced by people in their environment who have a car, they perceive that people in general look down on other travel modes than the car, and they sense a social pressure to obtain a driver's license and buy a car in the future. Travel disliking refers to students who feel frustrated in traffic, do not feel safe in traffic, and think that public transport is rather complicated.

Based on the past attitudes toward travel modes, two possible factors are identified: pro-active and public transport (PT), and pro-car/motorcycle (Table 2). During secondary education, students with pro-active and PT attitudes valued travelling by foot, bicycle, and public transport better. While students with pro-car/motorcycle attitudes appreciated travelling by car or motorcycle. 
Table 2: Pattern matrix of past attitudes toward travel modes $(\mathrm{N}=404)$

Kaiser-Meyer-Olkin Measure of Sampling Adequacy: 0.615

Bartlett's Test of Sphericity: $\chi^{2}=187.863 ; \mathrm{df}=15 ; \mathrm{p}=0.000$

Besides the past attitudes, also the current attitudes toward travel modes were examined. Based on the current attitudes toward travel modes, three possible factors are identified: pro-active, pro-PT, and pro-car/motorcycle (Table 3). Students with pro-active attitudes appreciate travelling by foot or bicycle. Students with pro-PT attitudes value travelling by bus, tram or train better. Students with pro-car/ motorcycle attitudes rate travelling by car or motorcycle better. Based on Table 2 and Table 3, it can be argued that respondents' travel preferences have become more diverse. While respondents' past attitudes toward active travel and public transport seem to be considerably correlated (as the representing variables are grouped together in one factor), their current attitudes toward active travel and public transport are less correlated (as the representing variables are split in two factors).

Table 3: Pattern matrix of current attitudes toward travel modes $(\mathrm{N}=404)$

\begin{tabular}{lccc}
\hline & Pro-active & Pro-PT & Pro-car/motorcycle \\
\hline Bicycle & 0.760 & & \\
By foot & 0.458 & & \\
Bus or tram & & 0.604 & \\
Train & & 0.553 & \\
Car & & & 0.492 \\
Motorcycle & & & 0.449 \\
\hline
\end{tabular}

Kaiser-Meyer-Olkin Measure of Sampling Adequacy: 0.618

Bartlett's Test of Sphericity: $\chi^{2}=205.885 ; \mathrm{df}=15 ; \mathrm{p}=0.000$

\section{$4 \quad$ Results}

The past and current impact of socio-economic and demographic (SED) characteristics, the built environment, the social network, the lifestyle, and trip characteristics on the choice of travel mode to school, grocery stores, and fun shops will be analyzed. As it is important to get a better understanding of why young adults up till now still use the car so often, we will focus on car use. The car is however barely used to go to school, grocery shopping, or fun shopping by students living in student dorms. Therefore, car use of students in dorms will be disregarded. All the variables in the models are significant at the $95 \%$ confidence level. The tables also include some non-significant p-values, which is a shortcoming of the conditional forward selection method used. 


\subsection{Trips to school}

In the past, no pupils went to school by car alone, the chosen reference category to define the travel company in "Block 3: Social network." If they went to school by car, all pupils were accompanied by family, other pupils, or friends. Because there is no variation in this social network variable, we chose to adjust our model by removing this block. The choice to commute to school by car was, according to our model, only influenced by the lifestyle. It appears that pupils who liked to travel by car or motorcycle and tend to find car use rather cheap, were more likely to travel by car. There was already a positive attitude toward cars present. However, the perceived low price to use the car reflects more the travel behavior of the parents than that of the pupils. If we consider Nagelkerke $\mathrm{R}^{2}$, the lifestyle variables only contribute to a limited extent in explaining car use variance of pupils to secondary school (Table 4).

Table 4: Past travel behavior of pupils to school by car $(\mathrm{N}=249)$

\begin{tabular}{|c|c|c|c|c|c|c|}
\hline & B & S.E. & Wald & df & Sig. & $\operatorname{Exp}(B)$ \\
\hline Block 1: SED characteristics & & & & & & \\
\hline \multicolumn{7}{|l|}{ Block 2: Built environment } \\
\hline \multicolumn{7}{|l|}{ Block 3: Lifestyle } \\
\hline \multicolumn{7}{|l|}{ Feature car: } \\
\hline Cheap & 1.999 & 0.973 & 4.223 & 1 & 0.040 & 7.381 \\
\hline $\begin{array}{l}\text { Block 4: Trip characteristics } \\
\text { - }\end{array}$ & & & & & & \\
\hline Constant & -2.577 & 0.279 & 85.086 & 1 & 0.000 & 0.076 \\
\hline Model Fit & $\mathrm{Chi}^{2}$ & df & Sig. & $-2 \mathrm{LL}$ & Cox \& Snell $\mathbf{R}^{2}$ & Nagelkerke $\mathbf{R}^{2}$ \\
\hline $\begin{array}{l}\text { Block 1: SED characteristics } \\
+ \text { Block 2: Built environment }\end{array}$ & - & & & & & \\
\hline $\begin{array}{l}\text { + Block 3: Lifestyle } \\
\text { + Block 4: Trip characteristics }\end{array}$ & $\begin{array}{c}12.489 \\
-\end{array}$ & 2 & 0.002 & 145.410 & 0.049 & 0.104 \\
\hline
\end{tabular}

To analyze the current travel behavior to university or university colleges, we were able to use "Block 3: Social network." The choice to commute by car to higher education institutions is influenced by socio-economic and demographic (SED) characteristics, the built environment, and the lifestyle (Table 5). Students who hold a degree in general secondary education appear to be more likely to use the car to go to higher education institutions. This can probably be explained by the fact that it is more common to pursue an academic or professional degree at a university or university college following general secondary education. Students holding a driver's license (and owning a personal car) are also more likely to travel by car. Besides the socio-economic and demographic characteristics, the choice to commute by car is also influenced by the residential environment. Students who live in a more rural environment are more likely to use the car. Further, commuting students who like to travel in an active manner are less likely to use the car compared to other travel modes. Commuting students also tend to find car use rather cheap. The independent variables explain a considerable amount of variance in current car use for going to university or university college. A possible explanation for this good fit is that students now have more socio-economic resources, such as a driver's license (and a personal car), to use the car according to their residential location and lifestyle. 
Table 5: Current travel behavior of commuting students to school by car $(\mathrm{N}=246)$

\begin{tabular}{|c|c|c|c|c|c|c|}
\hline & B & S.E. & Wald & df & Sig. & $\operatorname{Exp}(B)$ \\
\hline \multicolumn{7}{|l|}{ Block 1: SED characteristics } \\
\hline General secondary education & 2.288 & 0.919 & 6.196 & 1 & 0.013 & 9.859 \\
\hline Owning a driver's license & 2.425 & 0.764 & 10.079 & 1 & 0.001 & 11.306 \\
\hline Owning a car & 1.160 & 0.689 & 2.835 & 1 & 0.092 & 3.190 \\
\hline \multicolumn{7}{|l|}{ Block 2: Built environment } \\
\hline Urbanized environment & -1.695 & 0.628 & 7.280 & 1 & 0.007 & 0.184 \\
\hline \multicolumn{7}{|l|}{ Block 3: Social network } \\
\hline \multicolumn{7}{|l|}{ Block 4: Lifestyle } \\
\hline Pro-active attitude & -0.683 & 0.316 & 4.659 & 1 & 0.031 & 0.505 \\
\hline \multicolumn{7}{|l|}{ Feature car: } \\
\hline Cheap & 2.878 & 1.356 & 4.506 & 1 & 0.034 & 17.786 \\
\hline \multicolumn{7}{|l|}{ Block 5: Trip characteristics } \\
\hline Constant & -5.736 & 1.145 & 25.099 & 1 & 0.000 & 0.003 \\
\hline Model Fit & $\mathrm{Chi}^{2}$ & df & Sig. & $-2 \mathrm{LL}$ & Cox \& Snell $\mathbf{R}^{2}$ & Nagelkerke $\mathbf{R}^{2}$ \\
\hline Block 1: SED characteristics & 41.012 & 3 & 0.000 & 97.700 & 0.154 & 0.356 \\
\hline + Block 2: Built environment & 48.883 & 4 & 0.000 & 89.829 & 0.180 & 0.418 \\
\hline + Block 3: Social network & - & & & & & \\
\hline + Block 4: Lifestyle & 57.094 & 6 & 0.000 & 81.618 & 0.207 & 0.481 \\
\hline + Block 5: Trip characteristics & - & & & & & \\
\hline
\end{tabular}

\subsection{Trips to grocery stores}

Travel behavior during secondary school was probably influenced by socio-economic and demographic characteristics, the social network, and the lifestyle (Table 6). Pupils who have two working parents have a higher probability to go grocery shopping by car. If the trip was made with family members, there appeared to be a larger probability that the car was being used. In the past however, it were mainly the parents that made the decision to go grocery shopping by car and not the pupil, but it does give an indication of the image that pupils get during secondary education of the combination of car use and grocery shopping. Safety is for this activity not necessarily associated with car use. The contribution of the independent variables in explaining the variance of past car use to grocery stores can be considered as good. 
Table 6: Past travel behavior of pupils to grocery stores by car $(\mathrm{N}=232)$

\begin{tabular}{|c|c|c|c|c|c|c|}
\hline & B & S.E. & Wald & df & Sig. & $\operatorname{Exp}(B)$ \\
\hline \multicolumn{7}{|l|}{ Block 1: SED characteristics } \\
\hline Dual-earner household & 1.464 & 0.659 & 4.936 & 1 & 0.026 & 4.325 \\
\hline \multicolumn{7}{|l|}{$\begin{array}{l}\text { Block 2: Built environment } \\
\text { - }\end{array}$} \\
\hline \multicolumn{7}{|l|}{ Block 3: Social network } \\
\hline Travel company (ref. nobody): & & & 68.198 & 4 & 0.000 & \\
\hline Friends & 1.344 & 0.772 & 3.028 & 1 & 0.082 & 3.834 \\
\hline Family & 4.591 & 0.582 & 62.224 & 1 & 0.000 & 98.593 \\
\hline Pupils & -18.447 & $17,186.502$ & 0.000 & 1 & 0.999 & 0.000 \\
\hline Acquaintances & 23.202 & $40,192.969$ & 0.000 & 1 & 1.000 & $11,928,391,843.941$ \\
\hline \multicolumn{7}{|l|}{ Block 4: Lifestyle } \\
\hline \multicolumn{7}{|l|}{ Feature car: } \\
\hline Safe & -1.785 & 0.468 & 14.522 & 1 & 0.000 & 0.168 \\
\hline \multicolumn{7}{|l|}{ Block 5: Trip characteristics } \\
\hline Constant & -3.464 & 0.775 & 19.964 & 1 & 0.000 & 0.031 \\
\hline Model Fit & $\mathrm{Chi}^{2}$ & df & Sig. & $-2 \mathrm{LL}$ & Cox $\&$ Snell $\mathbf{R}^{2}$ & Nagelkerke $\mathbf{R}^{\mathbf{2}}$ \\
\hline Block 1: SED characteristics & 3.937 & 1 & 0.047 & 310.752 & 0.017 & 0.023 \\
\hline + Block 2: Built environment & - & & & & & \\
\hline + Block 3: Social network & 133.885 & 5 & 0.000 & 180.804 & 0.438 & 0.591 \\
\hline + Block 4: Lifestyle & 150.253 & 6 & 0.000 & 164.436 & 0.477 & 0.642 \\
\hline + Block 5: Trip characteristics & - & & & & & \\
\hline
\end{tabular}

Travel behavior of commuting students who go grocery shopping by car is influenced by almost the same blocks as in the past but in a slightly different way (Table 7). Holding a driver's license increases the probability of using a car to go grocery shopping. The car is probably mostly used if the trip is made with family. If students attach importance to comfort, there appears to be a larger probability that they will use the car to go grocery shopping. But safety is probably also for this activity not necessarily associated with car use. The overall travel distance is significant. The car is probably used for rather medium-long distances. The individual travel distances are however not significant, which is presumably caused by a low presence of students who actually travel by car in the used last reference category of $>20 \mathrm{~km}$ $(2.5 \%)$, while there were even no observations in the first category. The model of the current travel behavior is rather similar to that of the past travel behavior, and the independent variables also explain a large amount of variance in the dependent variable. But there are some differences noticeable. Holding a driver's license is an important element that can facilitate students' car use. The influence of the social network, especially the parents, remains important but appears to be less strong (given the somewhat lower contribution by this block in the current model compared to the past model). The attitude toward the car, appreciating comfort, is now more intuitively understandable than in the past. 
Table 7: Current travel behavior of commuting students to grocery stores by car $(\mathrm{N}=230)$

\begin{tabular}{|c|c|c|c|c|c|c|}
\hline & B & S.E. & Wald & df & Sig. & $\operatorname{Exp}(B)$ \\
\hline \multicolumn{7}{|l|}{ Block 1: SED characteristics } \\
\hline Woman & 0.565 & 0.472 & 1.433 & 1 & 0.231 & 1.760 \\
\hline Owning a driver's license & 2.987 & 0.634 & 22.183 & 1 & 0.000 & 19.825 \\
\hline Car availability & 0.354 & 0.447 & 0.627 & 1 & 0.429 & 1.424 \\
\hline \multicolumn{2}{|l|}{ Block 2: Built environment } & & & & & \\
\hline \multicolumn{7}{|l|}{ Block 3: Social network } \\
\hline Travel company (ref. nobody): & & & 39.621 & 3 & 0.000 & \\
\hline Friends & 0.893 & 0.814 & 1.203 & 1 & 0.273 & 2.442 \\
\hline Family & 3.334 & 0.543 & 37.698 & 1 & 0.000 & 28.060 \\
\hline Students & -19.003 & $40,192.970$ & 0.000 & 1 & 1.000 & 0.000 \\
\hline \multicolumn{7}{|l|}{ Block 4: Lifestyle } \\
\hline \multicolumn{7}{|l|}{ Feature car: } \\
\hline Comfort & 1.788 & 0.527 & 11.515 & 1 & 0.001 & 5.979 \\
\hline Safety & -0.762 & 0.447 & 2.904 & 1 & 0.088 & 0.467 \\
\hline \multicolumn{7}{|l|}{ Block 5: Trip characteristics } \\
\hline Distance (ref. > 20 km): & & & 13.898 & 6 & 0.031 & \\
\hline$<500 \mathrm{~m}$ & -22.298 & $10,928.836$ & 0.000 & 1 & 0.998 & 0.000 \\
\hline $500 \mathrm{~m}-1 \mathrm{~km}$ & -0.821 & 1.447 & 0.322 & 1 & 0.570 & 0.440 \\
\hline $1-2 \mathrm{~km}$ & -0.313 & 1.418 & 0.049 & 1 & 0.825 & 0.731 \\
\hline $2-5 \mathrm{~km}$ & 1.156 & 1.420 & 0.663 & 1 & 0.416 & 3.176 \\
\hline $5-10 \mathrm{~km}$ & 1.044 & 1.449 & 0.519 & 1 & 0.471 & 2.841 \\
\hline $10-20 \mathrm{~km}$ & 0.226 & 1.586 & 0.020 & 1 & 0.887 & 1.254 \\
\hline Constant & -4.215 & 1.575 & 7.157 & 1 & 0.007 & 0.015 \\
\hline Model Fit & $\mathrm{Chi}^{2}$ & df & Sig. & $-2 L L$ & Cox \& Snell $\mathbf{R}^{2}$ & Nagelkerke $\mathbf{R}^{2}$ \\
\hline Block 1: SED characteristics & 36.697 & 3 & 0.000 & 272.059 & 0.147 & 0.200 \\
\hline + Block 2: Built environment & - & & & & & \\
\hline + Block 3: Social network & 109.949 & 6 & 0.000 & 198.807 & 0.380 & 0.514 \\
\hline + Block 4: Lifestyle & 122.386 & 8 & 0.000 & 186.371 & 0.413 & 0.559 \\
\hline + Block 5: Trip characteristics & 153.027 & 14 & 0.000 & 155.729 & 0.486 & 0.658 \\
\hline
\end{tabular}

\subsection{Fun shopping trips}

When students were in secondary school, fun shopping by car was mostly explained by their social network and the lifestyle (Table 8). If the fun shopping trip was made in the company of family, there was a higher probability that the car was being used compared to other travel modes. If the travel company consisted of friends or other pupils, they were probably also more likely to use the car to make the trip. Pupils who do not like to travel or like to travel by car were also more likely to use the car to go fun shopping. These independent variables explain a considerable amount of the variance in the dependent variable. 
Table 8: Past travel behavior of pupils for fun shopping by car $(\mathrm{N}=238)$

\begin{tabular}{|c|c|c|c|c|c|c|}
\hline & B & S.E. & Wald & df & Sig. & $\operatorname{Exp}(B)$ \\
\hline $\begin{array}{l}\text { Block 1: SED characteristics } \\
\text { - }\end{array}$ & & & & & & \\
\hline $\begin{array}{l}\text { Block 2: Built environment } \\
\text { - }\end{array}$ & & & & & & \\
\hline Block 3: Social network & & & & & & \\
\hline Travel company (ref. nobody): & & & 55.563 & 4 & 0.000 & \\
\hline Friends & 1.270 & 0.787 & 2.600 & 1 & 0.107 & 3.560 \\
\hline Family & 3.703 & 0.802 & 21.307 & 1 & 0.000 & 40.566 \\
\hline Pupils & 1.265 & 0.900 & 1.975 & 1 & 0.160 & 3.544 \\
\hline Strangers & -19.908 & $40,192.970$ & 0.000 & 1 & 1.000 & 0.000 \\
\hline Block 4: Lifestyle & & & & & & \\
\hline Travel liking attitude & -0.517 & 0.196 & 6.945 & 1 & 0.008 & 0.596 \\
\hline Pro-car attitude & 0.713 & 0.227 & 9.919 & 1 & 0.002 & 2.041 \\
\hline $\begin{array}{l}\text { Block 5: Trip characteristics } \\
\text { - }\end{array}$ & & & & & & \\
\hline Constant & -2.478 & 0.756 & 10.734 & 1 & 0.001 & 0.084 \\
\hline Model Fit & $\mathrm{Chi}^{2}$ & df & Sig. & $-2 L L$ & Cox \& Snell $\mathbf{R}^{2}$ & 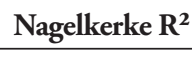 \\
\hline Block 1: SED characteristics & - & & & & & \\
\hline+ Block 2: Built environment & - & & & & & \\
\hline + Block 3: Social network & 65.177 & 4 & 0.000 & 262.337 & 0.240 & 0.321 \\
\hline + Block 4: Lifestyle & 80.531 & 6 & 0.000 & 246.983 & 0.287 & 0.384 \\
\hline + Block 5: Trip characteristics & - & & & & & \\
\hline
\end{tabular}

Travel behavior of students who commute to Ghent and go fun shopping by car is mostly explained by socio-economic and demographic characteristics, the social network, and the lifestyle (Table 9). Commuting students who have brothers or sisters are more likely to go fun shopping by car. Students with a personal car (and a car at their disposal) are also more likely to use the car. The chance to use the car to go fun shopping increases if the trip is made with family members. The car is probably preferred by students who dislike travel and who want to travel independently by car or motorcycle. The car is probably less used for rather short distances, as can be seen for $1-2 \mathrm{~km}$. This is however not visible for < $500 \mathrm{~m}$ and $500 \mathrm{~m}-1 \mathrm{~km}$, which is presumably caused by a low presence of students who actually travel by car in these categories, respectively $0.8 \%$ and $3.3 \%$. The overall travel distance is also not significant. The contribution of the independent variables in explaining the variance of car use for fun shopping is satisfactory. Compared to the model of the past, there is again a stronger influence of socio-economic and demographic characteristics. The influence of the social network, in particular the family, seems to be less strong and it appears that lifestyles are becoming somewhat more important. 
Table 9: Current travel behavior of commuting students for fun shopping by car $(\mathrm{N}=232)$

\begin{tabular}{|c|c|c|c|c|c|c|}
\hline & B & S.E. & Wald & df & Sig. & $\operatorname{Exp}(B)$ \\
\hline \multicolumn{7}{|l|}{ Block 1: SED characteristics } \\
\hline Brothers or sisters & 1.477 & 0.531 & 7.731 & 1 & 0.005 & 4.378 \\
\hline Owning a car & 1.156 & 0.469 & 6.082 & 1 & 0.014 & 3.177 \\
\hline Car availability & 0.663 & 0.412 & 2.591 & 1 & 0.107 & 1.940 \\
\hline \multicolumn{7}{|l|}{ Block 2: Built environment } \\
\hline Urbanized environment & -0.565 & 0.402 & 1.973 & 1 & 0.160 & 0.568 \\
\hline \multicolumn{7}{|l|}{ Block 3: Social network } \\
\hline Travel company (ref. nobody): & & & 38.778 & 4 & 0.000 & \\
\hline Friends & 1.485 & 1.112 & 1.784 & 1 & 0.182 & 4.415 \\
\hline Family & 3.891 & 1.116 & 12.161 & 1 & 0.000 & 48.938 \\
\hline Students & 2.677 & 1.440 & 3.453 & 1 & 0.063 & 14.536 \\
\hline Strangers & -17.876 & 27371.069 & 0.000 & 1 & 0.999 & 0.000 \\
\hline \multicolumn{7}{|l|}{ Block 4: Lifestyle } \\
\hline Travel disliking attitude & 0.419 & 0.248 & 2.843 & 1 & 0.092 & 1.520 \\
\hline Pro-PT attitude & -0.750 & 0.263 & 8.147 & 1 & 0.004 & 0.472 \\
\hline Pro-car/motorcycle attitude & 0.985 & 0.355 & 7.720 & 1 & 0.005 & 2.678 \\
\hline \multicolumn{7}{|l|}{ Block 5: Trip characteristics } \\
\hline Distance (ref. > $20 \mathrm{~km}$ ): & & & 11.433 & 6 & 0.076 & \\
\hline$<500 \mathrm{~m}$ & -21.291 & 28395.552 & 0.000 & 1 & 0.999 & 0.000 \\
\hline $500 \mathrm{~m}-1 \mathrm{~km}$ & -0.649 & 1.134 & 0.328 & 1 & 0.567 & 0.522 \\
\hline $1-2 \mathrm{~km}$ & -2.503 & 1.163 & 4.629 & 1 & 0.031 & 0.082 \\
\hline $2-5 \mathrm{~km}$ & -0.479 & 0.679 & 0.498 & 1 & 0.481 & 0.620 \\
\hline $5-10 \mathrm{~km}$ & -0.681 & 0.527 & 1.669 & 1 & 0.196 & 0.506 \\
\hline $10-20 \mathrm{~km}$ & 0.617 & 0.473 & 1.701 & 1 & 0.192 & 1.853 \\
\hline Constant & -4.366 & 1.288 & 11.499 & 1 & 0.001 & 0.013 \\
\hline Model Fit & $\mathrm{Chi}^{2}$ & df & Sig. & $-2 \mathrm{LL}$ & Cox \& Snell $\mathbf{R}^{2}$ & Nagelkerke $\mathbf{R}$ \\
\hline Block 1: SED characteristics & 33.355 & 3 & 0.000 & 283.837 & 0.134 & 0.180 \\
\hline + Block 2: Built environment & 39.776 & 4 & 0.000 & 277.416 & 0.158 & 0.211 \\
\hline + Block 3: Social network & 82.852 & 8 & 0.000 & 234.340 & 0.300 & 0.403 \\
\hline + Block 4: Lifestyle & 105.724 & 11 & 0.000 & 211.468 & 0.366 & 0.491 \\
\hline + Block 5: Trip characteristics & 122.186 & 17 & 0.000 & 195.006 & 0.409 & 0.549 \\
\hline
\end{tabular}

\section{$5 \quad$ Discussion and conclusion}

The hierarchical binary logistic regressions show that car use during secondary education is mainly explained by the travel company of family member(s) and lifestyles. These elements also explain modal choice during higher education in combination with socio-economic and demographic characteristics, the built environment and trip characteristics. Socio-economic and demographic characteristics become more outspoken with elements such as holding a driver's license or owning a car when young adults travel to educational institutions, grocery stores and fun shops. These resources facilitate car use according to the students' residential location and lifestyle. Besides the socio-economic and demographic 
characteristics, the built environment also becomes more important for going to university or university college by car, but not for doing groceries and fun shopping. If the residential environment is more rural, the chance to use the car to go to educational institutions becomes greater. It also appears that lifestyles become somewhat more important for fun shopping, because a slightly higher amount of variance in car use for fun shopping is being explained by the current lifestyle block compared to that of the past travel behavior. This was also found by Scheiner (2010) and Van Acker et al. (2011). This reflects that the emerging lifestyle becomes more individual and independent from the lifestyle of others, especially the parents, for leisure activities. This finding is also supported by the declining influence of social networks, in particular the family, in our model for fun shopping and grocery shopping. The trip characteristic travel distance seemed only important for current car use to grocery stores and fun shops, whereby young adults who live further away from grocery stores and fun shops are probably more likely to use the car. During the transition from secondary to higher education, the travel behavior of students who came to live in Ghent changed the most, although travel behavior of students commuting to Ghent also changed, but to a lesser extent (see Section 3.3). Based on the analysis of the questions in the questionnaire, it also became clear that young adults still attach importance to a car and feel social pressure to obtain a driver's license and to buy a car in the future.

If policy makers want to alter travel behavior in favor of more sustainable travel modes it is important to influence the variables affecting travel behavior, such as the built environment, lifestyles, and economic characteristics. An environment with a high density and diversity in combination with an adjusted design should encourage the use of public transport, cycling, and walking (Cervero \& Kockelman, 1997; De Vos, 2015; Ewing \& Cervero, 2010; Næss, 2014; Næss, Cao, \& Strand, 2017). Besides changing the built environment, it is also important to influence young adults' attitudes because these are more stable. Our findings indicate that pro-active and pro-public-transport attitudes should be promoted since these related attitudes are associated with more sustainable travel modes. This should be combined with making car ownership and car use more expensive because we found that young adults perceive them as rather cheap. This can be supported by the economic characteristics such as holding a driver's license or owning a car that facilitate car use. Making it more difficult to obtain a driver's license and to buy or use a car can discourage car use. It is also important to note that the political planning horizon is rather short to change travel behavior if we keep in mind that attitudes will probably remain constant in the short term (Munters, 1992). If policy makers can develop a uniform policy over the long term, it should be possible to shape travel behavior of children in favor of more sustainable travel modes, for instance through educational programs.

Further research about travel behavior and young adults is necessary because this group is often neglected in scientific research. It is important to get a better understanding of young adults' travel behavior, especially because they develop their own defined lifestyle. The survey used in this paper, but also most other travel-related surveys, focuses on the individual student with a limited reference to wider social influences like impacts from parents and friends. The effect of the social environment provides interesting avenues for further research. This social environment of parents and friends can have a direct influence on travel behavior (as already indicated by our analysis), but an indirect influence might also exist, e.g., through the interaction with attitudes. Previous research has already indicated that family and friends might have an important influence on personal mobility attitudes (Baslington, 2008; Döring, Albrecht, Scheiner, \& Holz-Rau, 2014; Döring et al., 2015; Emond \& Handy, 2012; Haustein et al., 2009; Klöckner \& Matthies, 2012). Such indirect effects can be best analyzed with structural equation modelling (SEM). SEM can be considered as a set of simultaneously estimated interrelated regressions where a variable can be an independent variable in one regression and at the same time a dependent variable in another regression. This could give us better insights into mobility socialization and could 
explain young people's attitudes toward car use even better. SEM was not used in this paper because this current research is rather explorative. Furthermore, SEM can be quite data intensive. A general rule of thumb is that sample sizes need to be at least ten times the number of variables in the model. However, this might increase rapidly depending on type of SEM, multivariate non-normality of the data, model complexity, etc. (Hair, Hult, Ringle, \& Sarstedt, 2013). Travel behavior of students in higher education seems to be rather sustainable, but this does not imply that this behavior will be pursued in the future when they start searching for a job, have a job, or relocate. The data we used are not longitudinal and only give an indication about how travel behavior has changed. It would also be interesting to set up a panel study to analyze these possible changes more thoroughly through time.

\section{Acknowledgements}

This paper has benefited from the constructive comments and suggestions of two anonymous reviewers. 


\section{References}

Albrecht, J., Döring, L., Holz-Rau, C., \& Scheiner, J. (2014). The relevance of the place of childhood and adolescence for residential choice in later life. A life-course and intergenerational approach. Proceedings of the 94 th Annual Meeting of the Transportation Research Board, Washington DC.

Bagley, M. N., \& Mokhtarian, P. L. (2002). The impact of residential neighborhood type on travel behavior: A structural equations modelling approach. The Annals of Regional Science, 36(2), 279-297.

Baslington, H. (2008). Travel socialization: A social theory of travel mode behavior. International Journal of Sustainable Transportation, 2(2), 91-114.

Beige, S., \& Axhausen, K. W. (2006). Long-term mobility decisions during the life course: Experiences with a 20 retrospective survey. Zürich: Eidgenössische Technische Hochschule.

Ben-Elia, E., Alexander, B., Hubers, C., \& Ettema, D. (2014). Activity fragmentation, ICT and travel: An exploratory path analysis of spatiotemporal interrelationships. Transportation Research Part A, 68, 56-74.

Berrington, A., \& Mikolai, J. (2014). Young adults' license-holding and driving Behavior in the UK. Full Findings. London: RAC Foundation.

Cao, X. (2012). The relationships between e-shopping and store shopping in the shopping process of search goods. Transportation Research Part A, 46(7), 993-1002.

Cedersund, H. K., \& Henriksson, P. (2006). En modell för att pronostisera ungdommars Körkortstagande. [A model for forecasting young people's propensity to obtain a driving license.] Linköping: Statens vägoch transportforskningsinstitut VTI.

Cervero, R., \& Kockelman, K. (1997). Travel demand and the 3Ds: Density, diversity and design. Transportation Research Part D, 2(3), 199-219.

Chatterjee, K., Goodwin, P., Schwanen, T., Clark, B., Jain, J., Melia, S., Middleton, J., Plyushteva, A., Ricci, M., Santos, G., \& Stokes, G. (2017). Young people's travel — what's changed and why? Review and analysis. Bristol, UK: University of Oxford, University of West England, Bristol.

Dargay, J. M. (2001). The effect of income on car ownership: Evidence of asymmetry. Transportation Research Part A, 35, 807-821.

Deffner, J., Götz, K., Schubert, S., Potting, C., Stete, G., Tschann, A., \& Loose, W. (2006). Schlussbericht zu dem Projekt "Nachhaltige Mobilitätskultur." Entwicklung eines integrierten Konzepts der Planung, Kommunikation und Implementierung einer nachhaltigen, multioptionalen Mobilitätskultur. [Final report on the sustainable mobility culture project. Development of an integrated concept for the planning, communication and implementation of a sustainable, multi-functional mobility culture.] Frankfurt am Main: Institut für sozial-ökologische Forschung.

Delbosc, A. (2017). Delay or forgo? A closer look at youth driver licensing trends in the United States and Australia. Transportation, 44(5), 919-926.

Delbosc, A., \& Currie, G. (2013). Causes of youth licensing decline: A synthesis of evidence. Transport Reviews, 33(3), 271-290.

Delbosc, A., \& Currie, G. (2014a). Changing demographics and young adult driver license decline in Melbourne, Australia (1994-2009). Transportation, 41(3), 529-542.

Delbosc, A., \& Currie, G. (2014b). Using discussion forums to explore attitudes toward cars and licensing among young Australians. Transport Policy, 31, 27-34.

Deloitte. (2009). Connecting with Gen Y: Making cars cool again. Brussels: Deloitte.

De Vos, J. (2015). The influence of land use and mobility policy on travel behavior: A comparative case study of Flanders and the Netherlands. Journal of Transport and Land Use, 8(1), 171-190.

De Vos, J., Derudder, B., Van Acker, V., \& Witlox, F. (2012). Reducing car use: Changing attitudes or 
relocating? The influence of residential dissonance on travel behavior. Journal of Transport Geography, 22, 1-9.

De Vos, J., Mokhtarian, P. L., Schwanen, T., Van Acker, V., \& Witlox, F. (2016a). Travel mode choice and travel satisfaction: Bridging the gap between decision utility and experienced utility. Transportation, 43(5), 771-796.

De Vos, J., Van Acker, V., \& Witlox, F. (2016b). Urban sprawl: Neighborhood dissatisfaction and urban preferences. Some evidence from Flanders. Urban Geography, 37(6), 839-862.

Döring, L., Albrecht, J., Scheiner, J., \& Holz-Rau, C. (2014). Mobility biographies in three generationssocialization effects on commute mode choice. Transportation Research Procedia, 1(1), 165-176.

Döring, L., Albrecht, J., Scheiner, J., \& Holz-Rau, C. (2015). Mobility socialization in work trip biographies: Work trips over the life course of two generations. Proceedings of the 94 th Annual meeting of the Transportation Research Board (pp 11-15), Washington DC, January 2015.

Emond, C., \& Handy, S. (2012). Factors associated with bicycling to high school: Insights from Davis, CA. Journal of Transport Geography, 20, 71-79.

Ewing, R., \& Cervero, R. (2010). Travel and the built environment: A meta-analysis. Journal of the American Planning Association, 76(3), 265-294.

Goodwin, P. (2012). Three views on 'peak car.' World Transport Policy \& Practice, 17(4), 8-17.

Goodwin, P., \& Van Dender, K. (2013). 'Peak car' — Themes and conclusions. Transport Reviews, 33, 243-254.

Götz, K., \& Deffner, J. (2009). Eine neue Mobilitätskultur in der Stadt-praktische Schritte zur Veränderung. [A new mobility culture in the city-practical steps to change.] In Bundesministerium für Verkehr, Bau und Stadtentwicklung (eds.), Urbane Mobilität. Verkehrsforschung des Bundes für die kommunale Praxis (pp 39-52). Bremerhaven: Wirtschaftsverlag NW, Verlag Für Neue Wissenschaft.

Groves, R. M. (1989). Survey errors and survey costs. New York: John Wiley and Sons.

Hair, J. F., Hult, G. T. M., Ringle, C., \& Sarstedt, M. (2013). A primer on partial least squares structural equation modeling (PLS-SEM). Thousand Oaks, CA: Sage Publications, Inc.

Harms, S. (2007). From university to working life: Impact of a critical life event on travel mode choice. Paper presented at the 7th Biennial Conference on Environmental Psychology, Bayreuth, Germany, September 12, 2007.

Haustein, S., Klöckner, C. A., \& Blöbaum, A. (2009). Car use of young adults: The role of travel socialization. Transportation Research Part F, 12, 168-178.

Hjorthol, R. (2016). Decreasing popularity of the car? Changes in driving license and access to a car among young adults over a 25-year period in Norway. Journal of Transport Geography, 51, 140-146.

Hjorthol, R. J., \& Bjørnskau, T. (2005). Gentrification in Norway capital, culture and convenience. European Urban and Regional Studies, 12(4), 353-371.

Jamieson, L., Cunningham-Burley, S., \& Rawlins, E. (2012). Twenty + futures. ESRC Centre for Population Change, Briefing 8.

Jorritsma, P., \& Berveling, J. (2014). Niet autoloos, maar auto later. Voor jongvolwassen blijft de auto een aantrekkelijk perspectief. [Not carless, but car-later. For young adults the car is still an attractive proposition.] Den Haag: Kennisinstituut voor Mobiliteitsbeleid.

Kitamura, R. (1988). Life-style and travel demand. Transportation Research Board Special Report, 220, 149-489.

Kitamura, R., Mokhtarian, P. L., \& Laidet, L. (1997). A micro-analysis of land use and travel in five neighborhoods in the San Francisco Bay Area. Transportation, 24(2), 125-158.

Klinger, T., Kenworthy, J. R., \& Lanzendorf, M. (2013). Dimensions of urban mobility cultures - A 
comparison of German cities. Journal of Transport Geography, 31, 18-29.

Klöckner, C.A., \& Matthies, E. (2012). Two pieces of the same puzzle? Script-based car choice habits between the influence of socialization and past behavior. Journal of Applied Social Psychology, 42(4), 793-821.

Krantz, L. G. (1999). Rörlighetens mångfald och förändring. Befolkningens dagliga resande i Sverige 1978 och 1996. [Mobility diversity and change. Population's daily travels in Sweden in 1978 and 1996.] Göteborg, Sweden: Kulturgeografisk institutionen, Handelshögskolan vid Göteborgs Universitet.

Kroesen, M., Handy, S., \& Chorus, C. (2017). Do attitudes cause behavior or vice versa? An alternative conceptualization of the attitude-behavior relationship in travel behavior modeling. Transportation Research Part A, 101, 190-202.

Kuhnimhof, T., Armoogum, J., Buehler, R., Dargay, J., Denstadli, J., \& Yamamoto, T. (2012a). Men shape a downward trend in car use among young adults: Evidence from six industrialized countries. Transport Reviews, 32(6), 761-779.

Kuhnimhof, T., Buehler, R., Wirtz, M., \& Kalinowska, D. (2012b). Travel trends among young adults in Germany: Increasing multimodality and declining car use for men. Journal of Transport Geography, 24, 443-450.

Lanzendorf, M. (2003). Mobility biographies. A new perspective for understanding travel behavior. Paper presented at the 10th International Conference on Travel Behavior Research, Lucerne, August, 10-15, 2003.

Latinopoulos, C., Le Vine, S., Jones, P., \& Polak, J. (2013). On the move: Car, rail and bus travel trends in Scotland. London: RAC Foundation.

Le Vine, S., \& Jones, P. (2012). Making sense of car and train travel trends in Britain. London: RAC Foundation.

Le Vine, S., Jones, P., Lee-Gosselin, M., \& Polak, J. (2014). Is heightened environmental-sensitivity responsible for the drop in young adults' driving-license-acquisition rates? Journal of the Transportation Research Board, 2465, 73-78.

Le Vine, S., Polak, J., \& Kuhnimhof, T. (2013). Case study of Great Britain: Socioeconomic changes, and variations in driving trends by income and location. In Institut für Mobilitätsforschung/Institute for Mobility Research (Ed.), Mobility y: The emerging travel patterns of Generation Y (pp. 27-34). Munich: Institute for Mobility Research.

McDonald, N., \& Trowbridge, M. (2009). Does the built environment affect when American teens become drivers? Evidence from the 2001 National Household Travel Survey. Journal of Safety Research, 40(3), 177-183.

Meeus, B., \& De Decker, P. (2013). De geest van suburbia. [The spirit of suburbia.] Antwerpen-Apeldoorn: Garant.

Ministerie van de Vlaamse Gemeenschap. (1997). Ruimtelijk Structuurplan Vlaanderen: Integrale versie. [Spatial structure plan for Flanders: full version.] Brussels: Ministerie van de Vlaamse Gemeenschap.

Mokhtarian, P. L., \& Cao, X. (2008). Examining the impacts of residential self-selection on travel behavior: A focus on methodologies. Transportation Research Part B, 42(3), 204-228.

Müggenburg, H., Busch-Geertsema, A., \& Lanzendorf, M. (2015). Mobility biographies: A review of achievements and challenges of the mobility biographies approach and a framework for further research. Journal of Transport Geography, 46, 151-163.

Munters, Q. J. (1992). Bestaan leefstijlen (nog) wel? [Do lifestyles (still) exist?] Sociologische Gids, 39, $179-185$.

Noble, B. (2005). Why are some young people choosing not to drive? Proceedings of the European Transport Conference, Strasbourg, September 18-20, 2005. 
Nordbakke, S. (2002). Førerkort og bilbruk blant ungdom på 90-tallet. Tegn på endringer i ungdoms reisevaner? [Driving license and car use among youth in the '90s. Signs of changes in youth travel habits?] Oslo: Transportøkonomisk institutt.

Næss, P. (2014). Tempest in a teapot: The exaggerated problem of transport-related residential selfselection as a source of error in empirical studies. Journal of Transport and Land Use, 7(3), 57-79.

Næss, P., Cao, J., \& Strand, A. (2017). Which D's are the important ones? The effects of regional location and density on driving distance in Oslo and Stavanger. Journal of Transport and Land Use, 10(1), 945-964.

Office for National Statistics. (2013). Family spending, 2013 Edition. London: Office for National Statistics.

Ottmann, P. (2007). Critical life events in the German Mobility Panel. Paper Presented at the 7th Biennial Conference on Environmental Psychology, Bayreuth, Germany, September 12, 2007.

Sakaria, N., \& Stehfest, N. (2013). Millennials and mobility: Understanding the millennial mindset and new opportunities for transit providers. Retrieved from http://www.trb.org/Publications/ Blurbs/169527.aspx.

Scheiner, J. (2007). Mobility biographies: Elements of a biographical theory of travel demand. Erdkunde, 61, 161-173.

Scheiner, J. (2010). Social inequalities in travel behavior: Trip distances in the context of residential selfselection and lifestyles. Journal of Transport Geography, 18, 679-690.

Scheiner, J., \& Holz-Rau, C. (2013). A comprehensive study of life course, cohort, and period effects on changes in travel mode use. Transportation Research A, 47, 167-181.

Schwanen, T., \& Mokhtarian, P. L. (2005a). What affects commute mode choice: Neighborhood physical structure or preferences toward neighborhoods? Journal of Transport Geography, 13(1), 83-99.

Schwanen, T., \& Mokhtarian, P.L. (2005b). What if you live in the wrong neighborhood? The impact of residential neighborhood type dissonance on distance travelled. Transportation Research Part D, 10(2), 127-151.

Sivak, M., \& Schoettle, B. (2012). Recent changes in the age composition of drivers in 15 countries. Traffic Injury Prevention, 13(2), 126-132.

Stad Gent. (2016). Gent, meer dan studeren alleen. Actieplan studentenbeleid. [Ghent, more than studying. Student policy action plan]. Gent: Stad Gent.

Steunpunt Werk en Sociale Economie. (2015). Dalende arbeidsdeelname bij Vlaamse jongeren. [Declining employment among the Flemish youth.] Arbeidsmarktflits, 12 February 2015.

Swinnen, G., \& Valkeneers, G. (2002). De milieubewuste automobilist: Een onderzoek naar het koopen rijgedrag van Vlaamse chauffeurs. [The environmental conscious driver: An investigation into the buying and driving behavior of Flemish drivers.] Economisch en Sociaal Tijdschrift, 56, 437-471.

Van Acker, V. (2015). Peak car among Generation Y. Internal Research Report SEG. Ghent: Universiteit Gent.

Van Acker V. (2016). Lifestyle and modal choices: Defining, measuring and using the 'lifestyle' concept. Transportation Research Record, 2495, 74-82.

Van Acker, V. (2017). Peak car: A generational approach. Proceedings of the BIVEC-GIBET Transport Research Days 2017, Liège, Belgium, May 18-19.

Van Acker, V., Goodwin, P., \& Witlox, F. (2016). Key research themes on behavior, lifestyle, and sustainable urban mobility. International Journal of Sustainable Transportation, 10(1), 25-32.

Van Acker, V., Mokhtarian, P. L., \& Witlox, F. (2011). Going soft: On how subjective variables explain modal choices for leisure travel. European Journal of Transport and Infrastructure Research, 11(2), 115-146. 
Van Acker, V., van Wee, B., \& Witlox, F. (2010). When transport geography meets social psychology: Toward a conceptual model of travel behavior. Transport Reviews, 30(2), 219-240.

van Wee, B. (2002). Land use and transport: Research and policy challenges. Journal of Transport Geography, 10(4), 259-271. 